\title{
(Post)socijalnost u suvremenom potrošačkom prostoru
}

\author{
Sanja Stanić \\ Filozofski fakultet Sveučilišta u Splitu \\ Odsjek za sociologiju \\ e-mail:sstanic@ffst.hr
}

SAŽETAK U radu se kao reprezent suvremenih potrošačkih prostora razmatra trgovački centar. U ovim strukturama pažljivo su kombinirani sadržaji i ponuda, a kupovina se obavlja praktično i u ugodnom okruženju. Vrijeme kupovine i dokoličarskih aktivnosti stopili su se u jedinstveno vrijeme potrošnje, dok je sam prostor postao mjesto okupljanja i socijalne živosti. Temeljem rezultata istraživanja, u radu se raspravlja socijalnost u trgovačkom centru. Potrošački prostor promatran je kao mjesto interakcija između prostora i aktera, te aktera međusobno.

Postignuti nalazi pokazuju kako je trgovački centar kreirano okruženje, koje elementima interijera, atmosferikom i sadržajima odašilje poruku s temeljnim ciljem poticanja potrošnje. Premda se trgovački centar manifestira kao socijalno mjesto, a kupovina i potrošnja kao socijalne aktivnosti, socijalnost je u potrošačkom okruženju prividna i limitirana. Tehnologije sve više zamjenjuju rad prodavača, koji postaju dodaci uređajima, dok su tradicionalne odlike njihovog posla minimalizirane, a komunikacija neiskrena i naučena. Zaključuje se kako se u suvremenim potrošačkim prostorima socijalni odnosi transformiraju u postsocijalne, koje obilježava gubitak spontanosti i reciprociteta, dok odnosi sa stvarima zamjenjuju odnose s ljudima.

Ključne riječi: socijalnost, potrošnja, prostor, manipulacija, interakcije, prodavači, potrošači, postsocijalni odnosi.

\section{Uvod}

Tijekom posljednjeg desetljeća trgovački centri počinju dominirati središtima i predgrađima naših gradova, kao vizualni znakovi procesa ustupanja proizvodnih pred potrošačkim sadržajima. Iako su kod nas relativno novija pojava, masovna proizvodnja ovih katedrala potrošnje (Kowinski, 2002., Ritzer, 2005.), ili novih 
sredstava potrošnje (Ritzer, 2005.) ${ }^{1}$ započela je 1956. godine, otvaranjem prvog, planski izgrađenog, zatvorenog trgovačkog centra u SAD-u. Southdale Center, u Edini, predgrađe grada Minnesote, tada jedno od najvećih zatvorenih mjesta u SAD-u, izgrađen je prema ideji austrijskog arhitekta V. Gruena. Njegova zamisao bila je socijalno utemeljena, s primarnim ciljem da ovi prostori, stanovnicima naglo naraslog i raspršenog američkog predgrađa, zamijene nepostojeće središte grada. Međutim, Gruenova ideja nikada nije realizirana u cijelosti, nego je modificirana prema načelima ostvarivanja profita, pa su trgovački centri, više negoli socijalnoj afirmaciji američkog predgrađa, pridonijeli počecima moderne kulture kupovanja, te su zauvijek promijenili američki način kupovanja i trgovine (Ritzer, 1999::35).

Pojava trgovačkih centara vremenski je podudarna s obnovom Keynezijanske ekonomije $^{2}$ i opredjeljenjem da potrošnja treba postati "način života, ritual, duhovno zadovoljstvo i zadovoljenje ega, mjera socijalnog statusa, prihvaćenosti i prestiža" (Lebow, 1955.:7-8). Stoga se ove trgovačke forme, koje će s vremenom uključivati sve širu i obilniju potrošačku ponudu, mogu promatrati kao jedan od instrumenata poticanja potrošnje s ciljem održanja stalno rastuće proizvodnje. Kako bi što efikasnije ispunjavali tu funkciju, unutrašnji prostor trgovačkih centara postaje posebna kreacija, opremljena stimulativnim mehanizmima neopipljive manipulacije, u čijem se stvaranju podjednako angažiraju moderni dizajn i suvremena znanost. Na koncu, trgovački se centar afirmira kao "sinteza obilja i kalkulacije" (Baudrillard, 2003.:27).

Tijekom pedesetak godina postojanja trgovački centri su postali globalni fenomen. Uz masovnu potrošnju i unificiranost potrošačke ponude, globalizacija ove trgovačke forme donosi homogenizaciju potrošnje i potrošačkih praksi, ali i provođenja slobodnog vremena. U ovoj svjetski popularnoj trgovini, zahvaljujući pažljivo sjedinjenim sadržajima, s kupovinom se kombiniraju nekada odvojene i posebne aktiv-

1 Kod G. Ritzera sredstva potrošnje igraju istu posredujuću ulogu u potrošnji kao što sredstva proizvodnje igraju u teoriji proizvodnje K. Marxa. Prema Ritzeru postoji logičan problem u načinu kako Marx koristi koncept sredstava potrošnje, posebno u usporedbi sa sredstvima proizvodnje. Sredstva proizvodnje zauzimaju središnju poziciju između radnika i proizvoda, ona omogućuju kako proizvodnju roba, tako i eksploataciju radnika. Suprotno tome, sredstva potrošnje nisu sredstva, nego završni, krajnji produkti u njegovom modelu potrošnje; ona su stvari koje se konzumiraju, bilo nužne ili luksuzne. Drugim riječima, kod Marxa nema razlike između proizvoda koji se troše i sredstava potrošnje, dok Ritzer razlikuje sredstva potrošnje od onoga što se konzumira; fast food restorani različiti su od hamburgera koje u njima jedemo (Ritzer, 2005.:50).

2 J. M. Keynes (1883.-1946.) ekonomist, tvorac suvremene makroekonomije, zagovarao je intervenciju države u gospodarstvo kako bi se spriječile krize i recesije. Smatrao je da država u vrijeme prosperiteta i visoke zaposlenosti treba štedjeti i ne miješati se u gospodarstvo nego ga regulirati, a u vrijeme negativnih ciklusa (kriza) koji su prirodna pojava, država treba početi trošiti kako bi povećala agregatnu potražnju, smanjiti poreze i kamatne stope kako bi potaknula poduzetnike i stanovništvo, te omogućila likvidnost. Država mora osigurati milijune za trošenje, ali su privatnici ti koji će odlučiti kako, gdje i kada potrošiti. To su najvažnija načela (neo)keynezijazma (Deskar-Škrbić, 2009.). 
nosti zabave, dokolice i druženja, a sukladno tome se i, nekada odvojeno, vrijeme ovih aktivnosti sjedinjava u jedno jedinstveno vrijeme potrošnje. ${ }^{3}$ Najzad, implozija aktivnosti i vremena rezultira u svijet potrošnje naizgled bez granica ili ograničenja gdje je sve raspoloživo, bilo gdje, u bilo koje vrijeme (Ritzer, Stillman, 2001.:92). Evolucija trgovačkog centra bila je u znaku obuhvaćanja sve različitijih sadržaja, pa su ti prostori postali okupljališta i mjesta provođenja slobodnog vremena ${ }^{4}$, čime su opravdano zavrijedili epitet socijalnih mjesta. ${ }^{5}$ U tom pravcu usmjeren je i interes ovoga rada, u kojem se raspravlja socijalnost u suvremenom potrošačkom prostoru. Naime, postmoderni svijet obilježavaju ubrzani ritam života, sve veća uporaba i oslonac na tehnologije, te porast značenja stvari i posjedovanja. Na mikro razini promjene su vidljive kao rast individualizma i orijentacija na svijet roba, a na makro razini kao erozija zajednice i tradicije uz opću tehnologizaciju života. Navedene transformacije se reflektiraju i na socijalne odnose, pri čemu tradicionalne socijalne forme i odnosi slabe, uz intenziviranje individualizma, komodifikacije i otuđenja. Te su promjene teorijski afirmirane u konceptima postsocijalnih odnosa u kojima interakcije s objektima postaju učestalije i značajnije od interakcija s drugima, koji nastaju kada pojedinac povezuje svoje želje s objektom, potvrđuje se i proširuje objektom, kada subjekt postaje definiran objektom (Knorr Cetina, Bruegger, 2002.:178), te postsocijalnog svijeta koji je desocijaliziran, u kojem je komunikacija rutinska, neiskrena i naučena, te u kojem raste posredovanost tehnologijama (Ritzer, 2005.). ${ }^{6}$ Ovim je konceptima rukovođeno i razmatranje socijalnosti u suvre-

3 U SAD-u, 1990-ih bilo je 36650 trgovačkih centara, a dužina vremena provedena u ovim prostorima slijedila je odmah iza vremena koje Amerikanci provedu u domu, kući ili školi (Goss, 1993.).

4 Uz kupovinu, mnogobrojne usluge i ugostiteljstvo, trgovački centri nude i kulturnu potrošnju, zabavu, tematske parkove, akvarije, rekreativne sadržaje i drugo.Primjerice, Mall of America, Bloomington, Minnesota, sagrađen je 1992. godine s površinom od 390000 metara četvornih. Godišnje privlači više posjetitelja negoli Disney World, Graceland i Grand Canyon zajedno (Underhill, 2005.:21).

5 Socijalne funkcije trgovačkog centra potvrđene su i istraživanjima provedenim kod nas. Istraživanjem A. Lukić (2002.) pokazano je kako posjetitelji koriste Centar Kaptol kao mjesto okupljanja, komunikacije, susreta, razmjene informacija, rekreacije i provođenja slobodnog vremena, dok se sam trgovački centar doživljava kao prostor u kom posjetitelji izuzev kupovine, zadovoljavaju i potrebe za socijalnim kontaktima. Premda je istraživanjem trgovačkog centra King Cross, M. Jakovčić (2004) istaknuta trgovačka funkcija, koja je potvrđena analizom poslovnih prostora i istraživanjem posjetitelja, socijalna funkcija pronalazi se u činjenici da se broj posjetitelja koji u ovaj centar dolaze sami smanjuje tijekom dana, prema večeri.

6 Uzroke ovih promjena treba tražiti u širim relacijama i transformacijama društvene strukture, te posebice u sve značajnoj ulozi tehnologije u postmodernom društvu. Promjene obilježavaju većinu aspekata suvremenog življenja, a ne isključivo sferu potrošnje. O rasprostranjenosti otuđenja, komodifikacije i objektifikacije, što bi pripadalo konceptima postsocijalnih odnosa i postsocijalnog svijeta govore mnogi autori, primjerice Z. Bauman (2009.), G. Lipovetsky (1987., 2008.), J. B. Schor (1998., 2003., 2004.) i drugi. Specifičan primjer novih socijalnih odnosa je i online komunikacija, koja sasvim isključuje tjelesnu prisutnost drugoga. Studije koje su se bavile istraživanjima socijalnih utjecaja interneta pokazuju kako ova komunikacija slabi društveni život i povećava socijalnu izolaciju (Nie, 2001.). 
menom potrošačkom prostoru. Prema K. Knorr Cetina i U. Brueggeru, interakcije i komunikacije, kao bitni aspekti koji čine određeni prostor ili događaj socijalnim, mogu odavati tradicionalnu socijalnost ili socijabilnost, kao spontanu društvenost, uzajamnost i refleksivnost među ljudima (2002.:170). S druge strane, interakcije i komunikacije mogu ukazivati na gubitak socijabilnosti i porast otuđenosti, gdje odnose s drugima zamjenjuju odnosi s objektima (2002.:178).

\section{Metodološka napomena}

U potrošačkom prostoru odvija se interakcija i komunikacija između prostora i aktera, te aktera međusobno, što ovaj prostor čini socijalnim mjestom. Sukladno tome, temeljni je cilj razmotriti socijalni karakter potrošačkog prostora putem interakcija i komunikacija na razini (a) potrošačkog prostora s naglaskom na poruci koju materijalnim i nematerijalnim elementima odašilje akterima, te (b) aktera, potrošača i prodavača, pri čemu je orijentacija na njihovim reakcijama na prostor, odnosno druge aktere.

Istraživanje je provedeno u trgovačkom centru Mercatoru Solinu kod Splita (Stanić, 2008). U istraživanju je korišten kombinirani metodološki pristup uz uporabu kvalitativnih i kvantitativnih istraživačkih metoda. Pojedine metode primijenjene su sukladno ciljevima i istraživanim scenama, odnosno populacijama. Obuhvat objektivne stvarnosti i subjektivnog viđenja, kao utvrđivanje socio-ekonomskih obilježja populacije potrošača, te saznavanje stavova i mišljenja većeg broja pojedinaca o određenom društvenom fenomenu realiziran je metodom ankete $(\mathrm{N}=320)$. Shvaćanje i objašnjenje socijalne realnosti s ciljem otkrića, motiviralo je korištenje metode naturalističkog promatranja za izabrane scene prostora, te uporabu nestrukturiranog intervjua u istraživanju prodavača kao specifične skupine ispitanika.

\section{Potrošački prostor kao komunikator stimulativne poruke}

Građevine su oblik materijalne kulture, te odražavaju način života, socijalne odnose i razinu razvoja društva. Bilo kao spomenici, ili kao prozaičniji znakovi i simboli, one komuniciraju socijalna značenja i uključuju ideologiju, a prostor unutar, oko i između njih je proizveden i koji proizvodi (Goss, 1988.:392). ${ }^{7}$ Suvremeni potrošački prostori su ilustrativan primjer proizvodnje prostora u suvremenom

\footnotetext{
7 Novija društvena misao prilazi prostoru kao društvenom konstruktu; društvo stvara i transformira prostor. H. Lefebvre u djelu The Production of Space govori o prostoru kao socijalnom produktu, kompleksnoj socijalnoj konstrukciji. Socijalni prostor inkorporira socijalne akcije, akcije individualnih i kolektivnih subjekata (2008.:33). U tom kontekstu Lefebvre razvija konceptualnu trijadu kreacije prostora putem spacijalnih praksi, reprezentacije prostora i prostora reprezentacije (2008.:38-39). Temeljna ideja utjecala je i na radove suvremenih autora D. Harveya, E. Soye i drugih.
} 
društvu. Koliko god se malo pozornosti posvećuje njihovom vanjskom izgledu, utoliko se više polaže na uređenje unutrašnjosti. Razumijevanje utjecaja fizičkog okoliša na korisnikove interakcije ključno je za dizajnere koji uobličuju prostor i njegove elemente kako bi poticali međusobne kontakte i potencirali željene socijalne interakcije (Ozdemir, 2008.:227). Udobnim uređenjem i posebnim dizajnom stimuliraju se osjeti, kako bi se produžio boravak i povećala potrošnja, jer "koliko će kupac vremena provesti u trgovini zavisi od toga koliko mu je zanimljivo, udobno i zabavno" (Underhill, 2000.:33). Rezultati provedenih istraživanja potvrđuju da komponente interijera utječu na socijalne interakcije, a između ostaloga pokazao se utjecaj umjetnog osvjetljenja, boje i visine plafona, tipa zatvorenosti i gustoće populacije (Ozdemir, 2008.:228).

Unutrašnjost trgovačkog centra Mercator je moderna, minimalistička, uz notu nenametljivog luksuza, što rezultira osjećajem distanciranosti. Taj je efekt postignut upotrebom oblika pravih i jednostavnih linija, materijala visokog sjaja, stakla, plastike, metala i kamena, te svijetlih sivo-plavih nijansi i neupadljivog, ali blistavog osvjetljenja. Prostornost je postignuta širokim ulicama, velikim trgom i prostranim trgovinama, čime je omogućeno lakše kretanje i umanjen osjećaj gužve.

Analizirani elementi unutrašnjosti sveukupno ukazuju kako se radi o ciljano kreiranom prostoru koji ima stimulativno i manipulativno djelovanje. Primjerice, brojnost ulaza u trgovački centar govori o otvorenosti i pristupnosti ove trgovine. Široka ulazna vrata, koja se sama otvaraju, olakšavaju kretanje s kolicima i vrećicama, a u istoj funkciji su i pokretne stepenice, čija brzina ima sigurnosnu dimenziju, dok istodobno sporo kretanje omogućuje i prilagodbu, te razgledavanje okolnih sadržaja. Ulaz kao "zona prelaska" (Underhill, 2000.:46) ili "zona dekompresije" (Underhill, 2005.:48), služi postupnoj akomodaciji na unutrašnje uvjete.

Važan element unutrašnje arhitekture je tlocrt, kao ključni čimbenik rješavanja tenzija između imidža i funkcije (Jewell, 2001.:344). U ovom trgovačkom centru je korišten pravokutno-kružni plan, znakovit za ranija razdoblja razvitka trgovačkih centara, koji je jednostavan za snalaženje, ali efektivan za trgovce, jer osigurava prolaženje cijelim krugom, čime su svi sadržaji podjednako izloženi pogledima potrošača. ${ }^{8}$

Interijeri trgovina, razmještaj polica, proizvoda i ostalih stvari usklađeni su s ljudskom anatomijom, načinima reagiranja i kretanja. Ulazi u trgovine su široki, bez

\footnotetext{
8 Razvitak tlocrta trgovačkih centara išao je u pravcu sve veće složenosti, pa unutrašnjost sve više nalikuje labirintima u kojima se kupci vrlo teško snalaze. Najsloženijim se smatra šesterokutni tlocrt u kojemu je navigacija dokazano najteža. Kompliciranje unutrašnjosti trgovačkih centara još je jedna od strategija kojima se investitori služe kako bi kupce zadržali što duže. Uprava megamallova računa na dezorijentaciju kupaca; Mi želimo da se vi izgubite, rekao je dizajner Tim Magill na otvorenju Mall of America (Rushkoff, 2002.:90). Prema J. Gossu kod velikih trgovačkih centara plan odražava jaku centripetalnu silu koja uvlači kupca u fantaziju (1993.:21).
} 
ulaznih vrata, a prijelaz s ulice je bez prepreka, obilježen promjenom podloge po kojoj se hoda. Izlozi su decentno i ukusno uređeni, te neupadljivo, ali efektno osvijetljeni, jer svjetlo je "tihi prodavač" što ukazuje na najskuplje robe, podešeno prema raspoloženju ili osjećajima koji se žele potaknuti kod kupca (Goss, 1993.:32).

Raspored stvari je poseban način "pasivnog iznuđivanja" (Rushkoff, 2002.:107) i primjer primjene znanosti o kupovanju (Underhill, 2000.:11). Razmještaj polica i roba u trgovinama, pa čak i smještaj košarica za kupovinu raspoređen je sukladno načinima kretanja i reagiranja kupaca. Primjer rasporeda u prostoru su i kafići, podijeljeni na "uvučeni" dio i štekat na ulici, kao i manje montažne trgovine, postavljene na frekventnim mjestima ulica i trga, koje su tako uočljive i dostupne iz više smjerova.

Budući je, sukladno izvornoj ideji, simulacija grada, prostor trgovačkog centra sadrži urbane elemente poput ulica sa štekatima i klupama uz ponešto zelenila, te trg s ugostiteljskim sadržajima i fontanom. Slično realnom središtu grada, ulice i trg imaju funkciju kretanja, šetnje, razgledavanja izloga i socijalizacije. U Mercatoru trg je otvoren, bez čvrstih pregrada, dok su iluzorne granice, kojima se usmjerava kretanje, date razmještajem ugostiteljskih sadržaja i prostorom fontane. Međutim, razlike između urbanog originala i simulacije su brojne; od savršenosti oblika, temperature i čistoće, do opreme simulacije uređajima sigurnosti, kao i znakovima zabrana i informacija?

Izuzev materijalnih, prostor trgovačkog centra obiluje i neopipljivim elementima kojima se postiže kreirani ugođaj, atmosferika, kao "tihi jezik komunikacije" (Rushkoff, 2002.:98) i psihološki način manipuliranja kupcima. Skup elemenata koji sačinjavaju atmosferiku je brojan. Materijali, boje i svjetlo, prizori i izlozi stimuliraju i eksploatiraju osjet vida. Ogledala i stakla uz stvaranje iluzije prostora, omogućuju ogledanje kupaca, ali i njihovu kontrolu. Podovi su udobni i bez prepreka, pa pogledi kupaca uvijek mogu biti "u ravnini očiju, usmjereni gdje treba, prema izlozima" (Underhill, 2005.:41). Površina za hodanje je sjajna, što je uobičajeno kod trgovačkih centara koji su namijenjeni klijenteli s visokim primanjima (Rushkoff, 2002::100). Čistoća i urednost u funkciji su stvaranja "utiska bezvremenosti čemu teži svaki trgovački centar" (Goss, 1993.:27). Ugođaj se postiže i laganom glazbom iz centralnog zvučnika, koja pridonosi ležernosti, razbija tišinu, te umanjuje ostale zvukove i šumove. Atmosferi pridonosi i uvijek ugodna temperatura, kao i upravljanje tijekom vremena, o čemu u trgovačkom centru Mercator, tek naslućujemo prema prodoru vanjskih utjecaja, kroz zatamnjene staklene zidove. Autori (Kowinski, 2002.; Ritzer 1999.; Goss, 1993.) navode kako je pravilo da u trgovačkim centrima nema prozora koji gledaju na vanjski svijet, niti ičega što će ukazati na protok vremena, doba dana, godišnje doba

\footnotetext{
9 Potrebno je naglasiti i razlike temeljem kriterija javnosti prostora. Ulice i trg trgovačkog centra kreirani su kako bi se dobio utisak da se radi o javnim prostorima, međutim, kao i u slučaju trgovina, riječ je o privatnom vlasništvu, odakle proizlaze mogućnosti ograničenja kretanja i kontrole ponašanja potrošača, te selekcija pristupa. Općeniti trend u suvremenom društvu je prostor u vlasništvu, odnosno, privatizacija javnih prostora uz nastanak tzv. semi-public space, prostora koji su samo prividno javni.
} 
ili lokaciju trgovačkog centra, a sve s ciljem da se kupci sasvim isključe iz realnosti i zaborave na vrijeme. ${ }^{10}$ Atmosfera bezvremenosti (Ritzer, 2005.; Kowinski, 2002.), stvara se eliminacijom svega što bi kupca moglo podsjetiti na protjecanje vremena i svijest o tome koliko se dugo zadržao u kupnji.

Biljke i voda u fontani osvježavaju umjetni prostor i podsjećaju na prirodu, dok s druge strane, priroda u neprirodnom okruženju "naturalizira potrošnju i ublažava alijenaciju svojstvenu proizvodnji i potrošnji roba" (Goss, 1993.:36). ${ }^{11}$ Fontana asocira na prirodnost i stvarnost urbanog prostora i njegove socijalne funkcije.

Tema trgovačkog centra Mercator prepoznatljiva je u nazivima ulica i trga, a trebala bi pobuditi nostalgiju za prošlim vremenima grada. ${ }^{12}$ Tematiziranje trgovačkog centra jedan je od načina vraćanja u prošlost čime se "eksploatiraju naša kolektivna svijest i povijesni korijeni" (Goss, 1993.:36).

Sigurnost i socijalna kontrola postignuta je znakovima zabrana kao što su primjerice znakovi na ulaznim vratima kojima se zabranjuje fotografiranje, pušenje, uvođenje ljubimaca, rolanje i neprikladna odjevenost. Zaštitu vlasništva tvrtke i kupaca jamče prisutni, ali nenametljivi zaštitari, koji će odstraniti svakoga tko odudara ponašanjem ili odjevenošću. Humani nadzor nadopunjavaju uređaji; vješto skrivene kamere, senzori i drugi sofisticirani načini kojima se kanalizira ponašanje i kretanje. Zaštitari i tehnologije su mehanizmi kontrole i ekskluzije, međutim, ipak je primarno "socijalna kontrola osigurana dizajnom i ona je eksplicitno i implicitno cilj dizajnera malla13" (Manzo, 2005.:85-86).

Temeljem prethodne analize interijera potrošačkog prostora proizlazi kako je cjelokupna unutrašnjost; uređenje, raspodjela prostora, upotrijebljeni materijali i boje, oprema pokućstvom i atmosfera, kreirana s namjerom da se što više produži vrijeme koje će kupac provesti u ovim prostorima. Radi se o tome da "dobro osmišljen prostor svoju poruku odašilje što izravnije, dajući nam mogućnost da je razumije-

10 Ovdje je riječ o načinu manipulacije putem osjećaja za vrijeme. Naime, 1950-ih godina psihologija je dokazala da je lakše manipulirati ljudima kojima je uskraćen osjećaj za vrijeme, što je prvobitno primjenjivano u kasinima iz kojih su izbačeni satovi i onemogućen prodor vanjskog svjetla (Rushkoff, 2002.). Iste su metode primijenjene kasnije u trgovačkim centrima.

$\mathbf{1 1}$ Kako bi se kreiralo prirodnije okruženje, u velikim trgovačkim centrima izgrađuju se prostrani vrtovi sa svim obilježjima realnih. J. Goss daje primjer Tyson's Cornera u Virginiji, čija je uprava odabrala 29 velikih palmi koje su iskopane u Floridi i čuvane 18 mjeseci u sjeni kako bi se aklimatizirale na uvjete u zatvorenom, prije nego što ih se smjesti u interijer trgovačkog centra (1993.:44).

12 Tema ovog trgovačkog centra je Velo misto, koja nije posebno naglašena kroz uređenje interijera kako je to uobičajeno u velikim, svjetskim trgovačkim centrima, ali je primjetna u nazivima trgovačkih ulica, te promidžbenim materijalima ovog trgovačkog centra.

$\mathbf{1 3}$ Shopping centre ili shopping center, shopping mall, ili samo mall, su sinonimi. Shopping center se u Americi popularno naziva shopping mall (Ritzer, 1999.), odnosno za zatvoreni, klimatizirani i osigurani prodajni prostor koristi se termin mall (Underhill, 2005.). 
mo, pa čak i da se radujemo tome kako djeluje na naše osjećaje", međutim, "ova scenografija naprosto je lukavština koja priprema pozornicu za cijeli niz manje uočljivih tehnika utjecaja” (Rushkoff, 2002.:81). Ključni moment koji omogućuje ovakve utjecaje istaknut će W. S. Kowinski, što je, prema ovom autoru, izdvajanje ovoga prostora od vanjskog svijeta, čime on postaje svijet za sebe, sa svojim pravilima i realnošću. Zatvorenost, zaštićenost i kontrola su "elementi koji čine mall ekstremno efikasnim prodajnim strojem... Kada imate prostor koji ste odvojili od vanjskog svijeta i kada imate mogućnost da stvorite svoj svijet iznutra, te da ga uredite po svojim pravilima, ono što imate je mogućnost magije" (2002.:92). ${ }^{14}$

\section{Stimulativni učinak prostora na potrošače}

Utjecaj poruke koju komunicira posebno dizajniran prostor razvidan je već u strukturi potrošačke populacije centra Mercator. Radi se o pretežito ženskoj populaciji $(66,6 \%)$, koja je mlade i relativno mlade dobi (42,3\% od 21. do 30. godine i $28,4 \%$ od 31. do 40.), te povoljne obrazovne strukture (48,4\% srednje i 25,6\% visoko obrazovanih). Većina posjetitelja su zaposleni (71,6\%), a među zanimanjima, prevladavaju službenička $(26,6 \%)$ i radnička $(23,8 \%)$, uz udio stručnjaka (15\%). Mjesečni prihodi većine njihovih kućanstava (61\%), nadilaze potrošački minimum, te se može govoriti o populaciji boljih kupovnih mogućnosti. Prema podacima, potrošačka se populacija pokazuje socijalno homogenom, što potvrđuje činjenica da se u određenim socioekonomskim obilježjima razlikuje od stanovništva grada Splita. U odnosu na ukupnu populaciju grada, pokazalo se kako su posjetitelji ovog trgovačkog centra zaposleniji, obrazovaniji i stručniji, ${ }^{15}$ što potvrđuje da specifični potrošački prostor privlači strukture određenih socijalnih i ekonomskih obilježja, istodobno isključujući druge. Socijalna jednoličnost koja se tako formira u potrošačkom prostoru sasvim je suprotna gradu čija je trgovački centar imitacija. Gradske ulice nisu u socijalnom aspektu strogo ograničena niti ekskluzivna mjesta, naprotiv, tipična gradska ulica je relativno demokratski prostor u kom svi građani imaju pristup i koji odlikuje mogućnost socijalnog miješanja (Zukin, 1998.:41).

${ }^{14}$ Korisno je napomenuti kako prema obilježjima prostora, trgovački centar pripada i u kategoriju nemjesta. Naime, prema M. Augéu, supermodernost proizvodi nemjesta, tranzitne i anonimne prostore koji omogućuju brzi protok velikog broja pojedinaca. Budući su lišeni identiteta, povijesti i značenja kao socijalnog konstrukta, nemjesta nisu antropološka mjesta. Nemjesta su, prema ovom autoru, prava mjera našeg doba, a tu pripadaju zračne, željezničke i cestovne komunikacije, prijevozna sredstva, zračne luke, svemirske postaje, veliki hotelski lanci, zabavišta, trgovački centri, kao i kablovske i bežične mreže koje iskorištavaju vanzemaljski prostor u svrhu komunikacije (Augé, 2002.).

15 Primjerice, prema popisu stanovništva iz 2001. godine u Splitu je bilo 15\% stanovništva u dobi od 20 do 29 godina, dok je u uzorku zastupljenost te populacije iznosila $42 \%$. Zamjetne razlike su i u aspektu obrazovne strukture. Iste je godine u Splitu bilo $27 \%$ stanovništva sa srednjom stručnom spremom, dok je u uzroku 48,4\% ispitanika te obrazovne razine. Slično je i s visokim i višim obrazovanjem; među stanovništvom Splita bilo je $12,3 \%$ visoko i $7 \%$ više obrazovanih, dok su u uzroku ove obrazovne strukture zastupljene s $26 \%$, odnosno $14,4 \%$. 
Ne samo da prostor djeluje privlačno na određene strukture, nego postoji i povratan utjecaj konkretiziran kao vjernost potrošačke populacije potrošačkom prostoru. Naime, kako pokazuju podaci (Prikaz 1.) više od polovine ispitanika (56\%) odano je ovom trgovačkom centru, bilo da posjećuju isključivo ovaj ili ga preferiraju u odnosu na druge.

Prikaz 1.

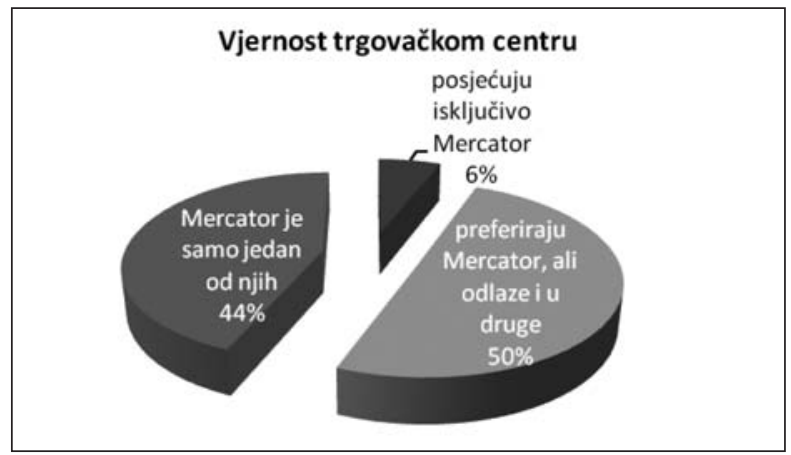

Efekt potrošačkog prostora na potrošače potvrđuju i atraktivni elementi (Prikaz 2.), među kojima su na prvom mjestu ispitanici istaknuli one koji sačinjavaju ugodu; klimatiziranost, prostranost, čistoću i urednost, te ljubaznost osoblja, što cijeni približno trećina ispitanika. Na drugom su mjestu aspekti koji omogućuju praktičnost obavljanja potrošnje: pristup automobilom, lokacija, veliki, besplatan parking, a na trećem je mjestu potrošačka ponuda. Unutar potrošačke ponude, povoljnost kupovine vrlo je nisko rangirana što sugerira kako se radi o izboru koji je namijenjen potrošačima boljeg materijalnog stanja.

Prikaz 2.

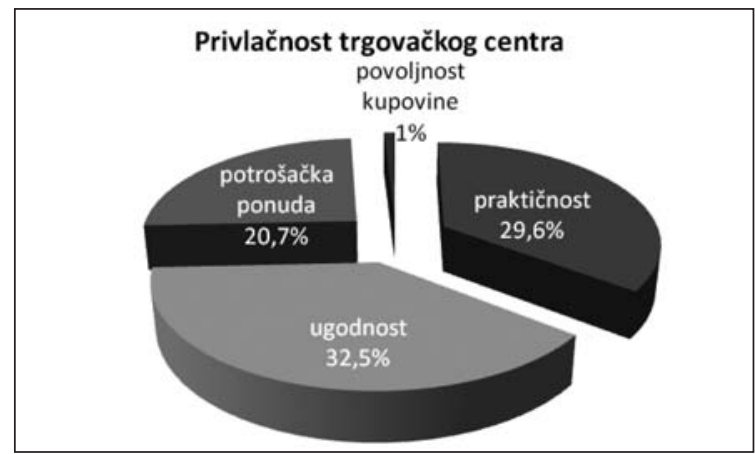


U procjeni negativnosti trgovačkog centra čak 27\% ispitanika smatra da ove strukture nemaju nikakvih negativnih strana. S druge strane, kritičniji potrošači pronalaze mane ovog prostora, pri čemu je indikativno da u najmanjem broju slučajeva osjećaju manipulaciju i kontrolu, što je istaknulo tek 7,2\%, odnosno 2,2\% ispitanika (Prikaz 3.). Ovi nalazi su iznimno važni jer potvrđuju dobru prikrivenost mehanizama kontrole i manipulacije u potrošačkom prostoru.

Prikaz 3.

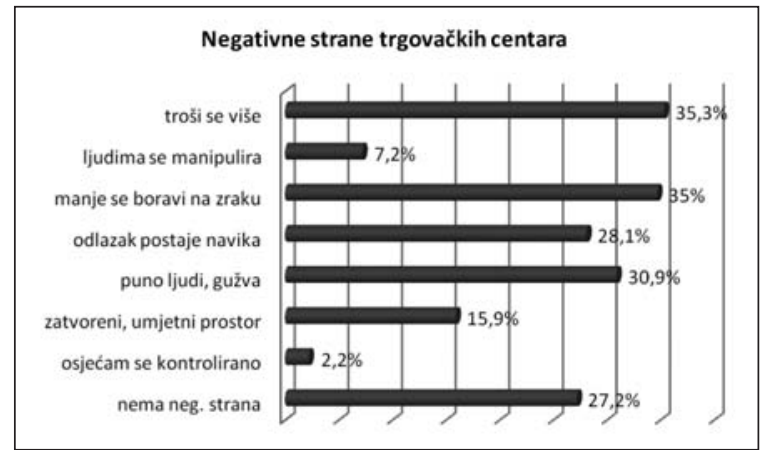

Treba ukazati da, pored obilježja prostora, atraktivnosti potrošačkog prostora pridonosi i široki spektar ukupne potrošačke ponude koja uz kupovinu, uključuje usluge, servise, ugostiteljstvo i zabavu, kao i prostore za relaksaciju i druženje. Obilnu i pažljivo složenu kombinaciju ponude u potpunosti konzumira nešto više od polovine ispitanika (Prikaz 4.), koji za jedne posjete trgovačkom centru kupuju, šeću i razgledavaju, popiju piće i druže se.

Prikaz 4.

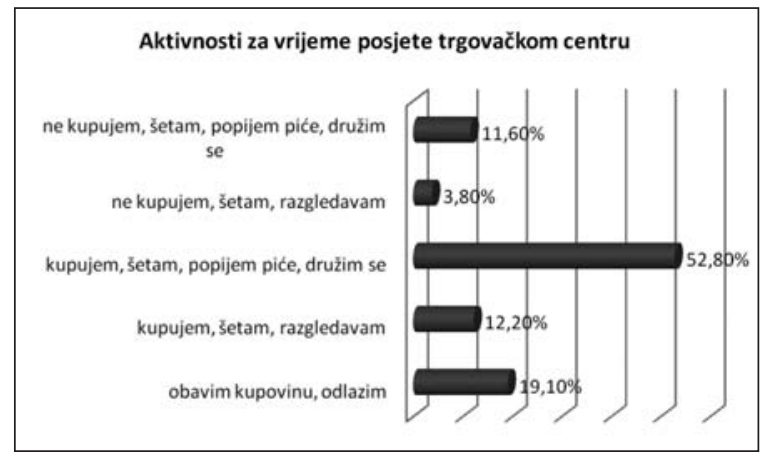

Sukladno prethodnim podacima je i vrijeme koje potrošači provedu u trgovačkom centru za jedne posjete, a ono je impresivno; četvrtina ispitanika proboravi u trgo- 
vačkom centru čak duže od tri sata, a nešto manje od polovine od jednog do dva sata (Prikaz 5.). Obrazloženje dužine provedenog vremena, uz raznoliku ponudu i mogućnost proširenja potrošnje, treba svakako promatrati i u okviru ranijih navoda o kreiranju i djelovanju prostora.

Prikaz 5.

\section{Najčešće trajanje posjete trgovačkom \\ centru}

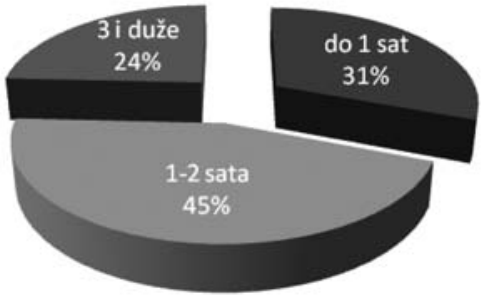

Učinak ugodnog prostora i kombinacije ponude na potrošače ponajbolje posvjedočuju podaci o neplaniranim kupovinama (Prikaz 6.), pri čemu čak 67\% ispitanika u ovom trgovačkom centru kupe i ono što prvotno nisu namjeravali.

Prikaz 6.

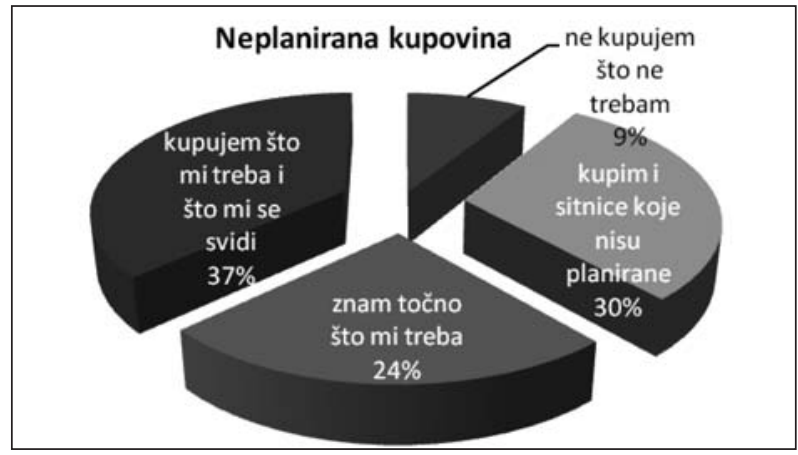

Uz neplanirane kupovine, stimulativnost prostora ilustriraju i podaci o tome koliko potrošači u kupovini udovoljavanju željama. Kako je vidljivo iz Prikaza 7., nešto više od polovine ispitanika koji kupuju u ovom trgovačkom centru, povremeno udovoljavaju svojim željama, a četvrtina njih to čini redovito. Podaci o neplaniranim kupovinama i učestalosti udovoljavanja željama još jednom potvrđuju kako Mercator privlači potrošačku populaciju boljih potrošačkih mogućnosti. 
Prikaz 7.

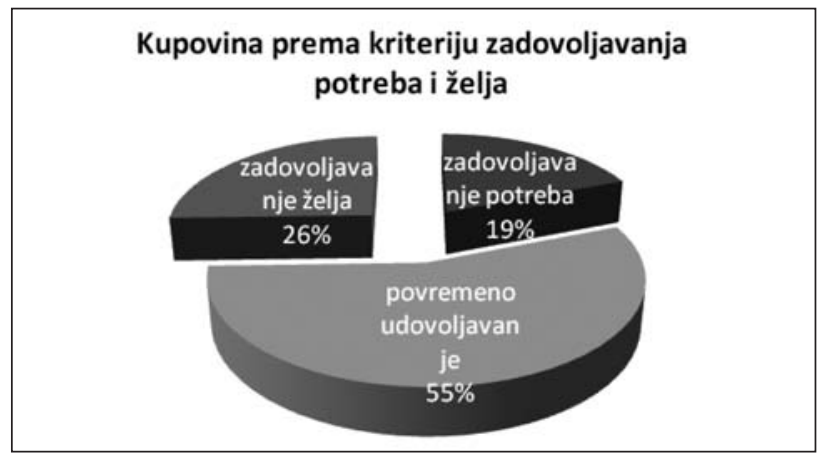

Promatrani sveukupno, prethodno predočeni podaci ilustriraju različite manifestacije stimulativnog djelovanja prostora na potrošače. Općenito se može kazati kako potrošački prostor privlači određene strukture potrošača, koje ga pronalaze atraktivnim primarno zbog ugode koja je u njemu ciljano kreirana. Potrošači su u većini vjerni "svom" trgovačkom centru, gdje mogu kupovati, razgledavati, popiti piće i družiti se, u čemu će provesti dva do tri sata ili čak i duže. Pri tome oni uočavaju kako ovaj potrošački prostor ima određene negativnosti, ali među njima ponajmanje osjećaju njegove manipulativne i kontrolabilne mehanizme. U takvom okruženju većina njih će kupiti i ono što nisu imali namjeru, te će povremeno ili redovito, uz potrebe, udovoljavati i svojim željama.

\section{Socijalnost potrošnje u trgovačkom centru}

Socijalni karakter potrošačkog prostora potvrđuju podaci o dolasku u trgovački centar, pri čemu čak 86,7\% ispitanika dolazi u društvu drugih (Prikaz 8). Pri tome su najčešća okruženja dolaska prijatelji i partneri, te nešto manje obitelj.

Prikaz 8.

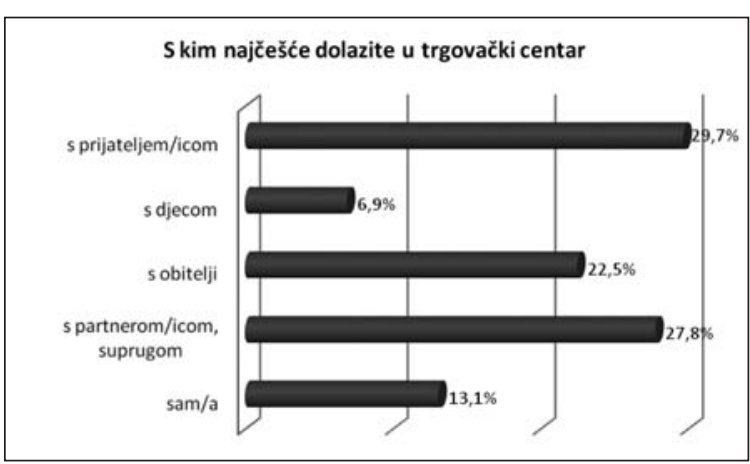


Ne samo dolazak, nego se i kupovina u trgovačkom centru pokazala kao socijalna aktivnost. Iz Prikaza 9. vidlijivo je kako velika većina ispitanika $(72,2 \%)$ preferira kupnju u društvu drugih.

Prikaz 9.

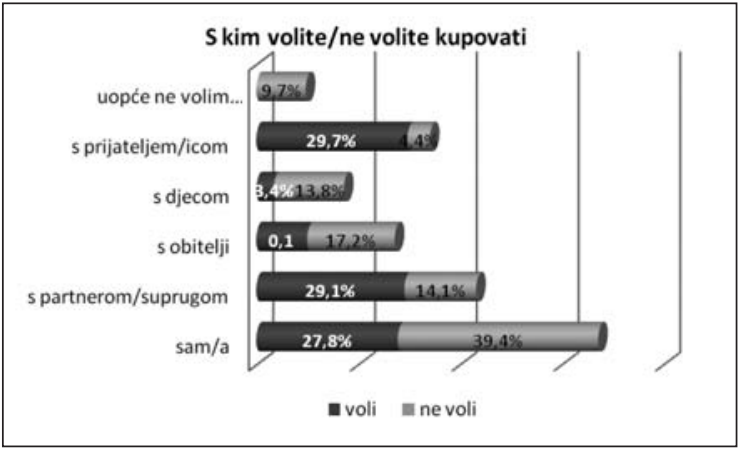

Međutim, u kupovini postoje preferirana i manje poželjna socijalna okruženja. Tako su ispitanici skloniji kupovinu obavljati u društvu prijatelja odnosno partnera, dok su obitelj i djeca manje poželjni u ovoj aktivnosti. Budući da najčešće uključuje društvo drugih, kupovina je obilježena socijalnim mikrosituacijama. Jedna od takvih su prepirke, koje obilježavaju kupovinu polovine ispitanika. Iz Prikaza 10. vidljivo je kako su prepirke motivirane različitim uzrocima, kroz koje se prelama socijalni karakter i socioekonomska uvjetovanost kupovine.

Prikaz 10.

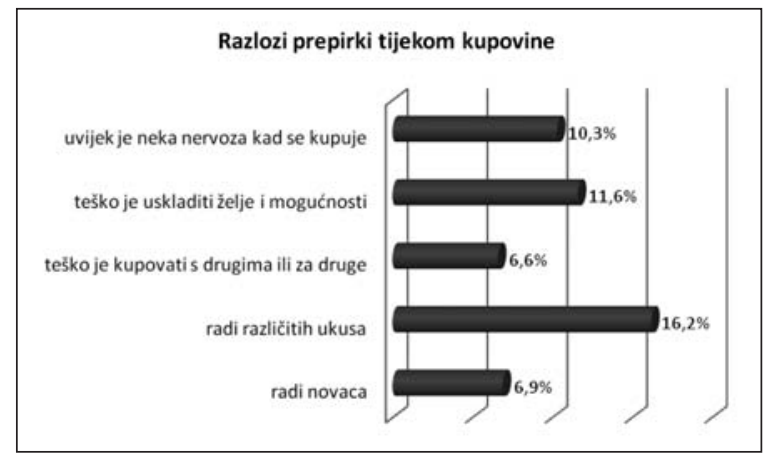

Kupovina općenito komunicira pozitivne osjećaje. Naime, prema podacima, ispitanici su zadovoljni nakon što obave kupovinu namirnica i potrepština, a posebice nakon što kupe stvari koje se ne kupuju svaki dan. U slučaju kupovine svakodnev- 
nih potrepština, kako pokazuju podaci iz Prikaza 11., zadovoljstvo je u najvećem broju slučajeva zbog obavljenog posla, što ovu kupovinu kvalificira kao posao i obvezu. Na drugom mjestu ono je uvjetovano kupovinom sitnica, te osobnim sklonostima ka kupovanju namirnica, što sugerira na ovu kupovinu kao način nagrađivanja, ugađanja $\mathrm{i}$ ispunjenja.

Prikaz 11.

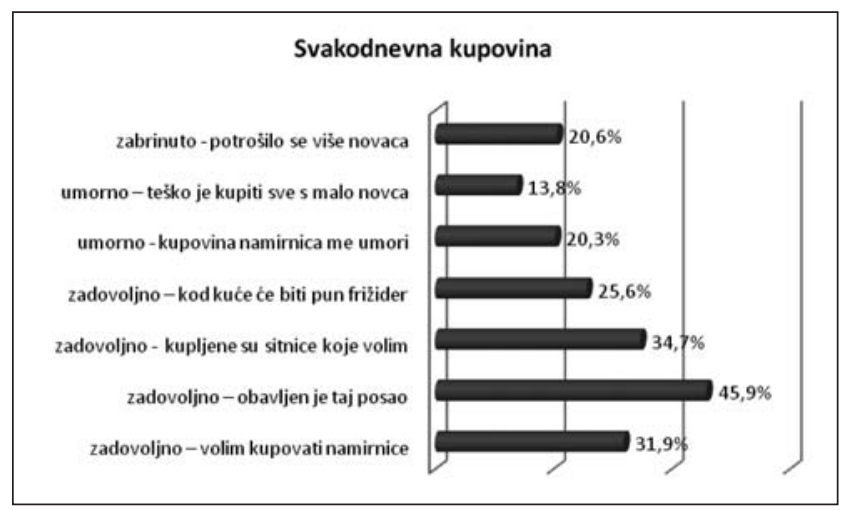

Prikaz 12. donosi podatke iz kojih je vidljivo da je kod nesvakidašnje kupovine, stvari kao što su odjeća, obuća i slično, zadovoljstvo ispitanika još izraženije negoli kod svakodnevne. U slučaju ove kupovine zadovoljstvo je na prvom mjestu uvjetovano samougađanjem, bilo da se kupilo nešto lijepo za sebe, ili se pak takve stvari vole kupovati. S druge strane, treba kazati kako negativne kategorije zabrinutosti i umora manje opterećuju nesvakidašnju kupovinu negoli svakodnevnu, što sve zajedno kategorizira nesvakodnevnu kupovinu kao užitak, indirektno kao užitak u kupljenim predmetima.

Prikaz 12.

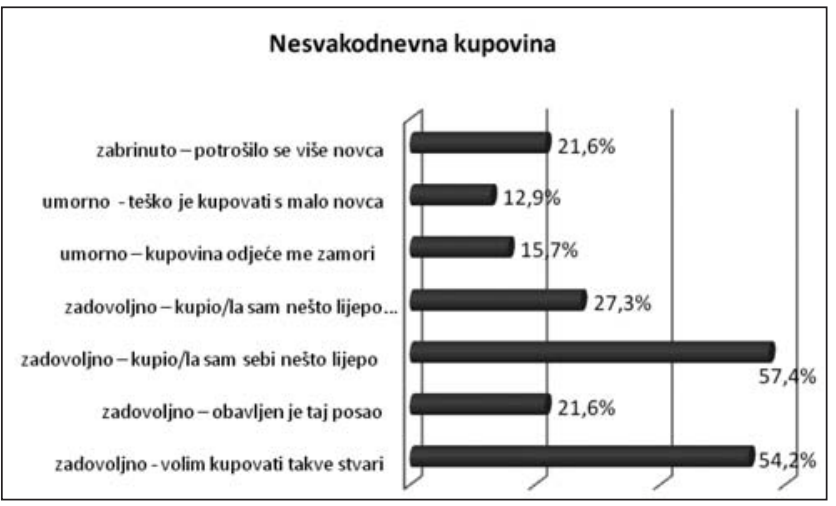


Analize socijalnih aspekata potrošnje nedvojbeno pokazuju kako se potrošački prostor pojavljuje kao socijalno mjesto, a potrošnja u tom prostoru kao socijalni događaj. Dakako da je socijalnost u ovom prostoru motivirana njegovim obilježjima u pogledu mogućnosti potrošnje i provođenja vremena. Već sam dolazak u trgovački centar je socijalni čin koji se nastavlja u kupovini kao socijalnoj aktivnosti u kojoj ipak, ma koliko ove strukture slovile kao obiteljska mjesta, obitelj i djeca nisu među poželjnijim društvima. Kupovina koja se ovdje obavlja, bila svakodnevna ili nesvakodnevna, provocira pozitivne osjećaje i doživljaje, koji su rezultat impulzivnosti, samougađanja i hedonizma.

\section{Interakcije $\mathrm{i}$ komunikacije prodavača}

Druga promatrana skupina aktera u trgovačkom centru su prodavači. Naspram prihvaćenosti trgovačkih centara i zadovoljstva potrošača, kod ovih zatvorenika malla (Kowinski, 2002.:409) prevladava nezadovoljstvo. Prema tvrdnjama ispitanice, ono proizlazi iz uvjeta rada, a u prvom redu zbog disproporcije dugog radnog vremena i primanja, te nemogućnosti upravljanja slobodnim vremenom: ...mi radimo $i$ po 50 sati tjedno. Ja sam imala 120 sati viška, to je tri tjedna ... ljeti sam mogla dobiti po jedan-dva dana usred tjedna... Zbog takvog radnog vremena često pati obiteljski život prodavača: Ja sam na godišnjem kad su djeca u školi, a kad su oni na praznicima ja radim. Dugogodišnji rad u trgovini sve je teže podnositi, a ispitanica ističe kako je to rad koji postupno "troši" radnika: Najviše me pogađa to što vidim da ce trgovina $i$ nadalje raditi sve više $i$ više, a ja to više ne mogu! ... Sve žene što ovdje rade četiri ili pet godina, ti su se ljudi maksimalno potrošili.

Nezadovoljstvo prodavača uvjetovano je interakcijom i komunikacijom s ostalim akterima u potrošnji, primarno s kupcima, ali i s kolegama i nadređenima. Interakcija prodavača s kupcima može se opisati kao odnos neravnopravnih, pri čemu je: Kupac kralj, on je uvijek u pravu... za kupca se sve čini... Iako među kupcima razlikuju one "dobre" i "loše", komunikacija prodavača s kupcima sastoji se u obveznom i ljubaznom minimumu naučenih i rutinski izgovorenih fraza: Mi moramo pozdraviti, zahvaliti, biti ljubazni, ali to je sve automatizam. Komunikacija prodavača često je jednosmjerna, jer kupci ne odgovaraju na ljubazne, ali mehaničke pozdrave i izjave prodavača. Međutim, prema riječima ispitanice, prodavači nisu indiferentni na neuvažavanje od strane kupaca: Meni smeta kad mi netko kaže "ti". Ja, kad mi dođe mlada cura, mlađa od mene, ja njoj govorim "vi".

Komunikacija s kolegama u radnom vremenu je rijetka, a onemogućena je radnim položajem u prostoru ili zbog preopterećenosti: Mi ne možemo popričati jer smo udaljene jedna od druge, a nemamo ni vremena za to. Prije negoli uzajamna solidarnost i pomoć, interakcije s kolegama označava negativan predznak; zavist, ogovaranje i špijuniranje: Mene su promatrali što radim, što sam obukla, je li mi tko došao... Kolegica bi dojavljivala poslovođi. 
Komunikaciju s nadređenima često određuje položaj u strukturi rada, pa nadređeni nemaju razumijevanja i u većini se s visoka odnose prema podređenima: Šefica je znala reći: Ja sam ovdje "Bog" i kako ja kažem tako mora biti!

Nezadovoljstvo prodavača proizlazi i iz obilježja prostora, u prvom redu radi nedostatka privatnosti u potpuno otvorenoj unutrašnjosti u kojoj: Svi vas vide što radite. Međutim, koliko otvorena unutrašnjost, toliko je problem i opća zatvorenost, što rezultira gubitkom osjećaja za vrijeme: Ja ne znam više ni koje je doba dana, kao i isključenosti iz vanjskih uvjeta: Ja ne znam što je i kako je vani.

Poseban vid komunikacije i interakcije prodavača u suvremenim prodajnim prostorima je nehumana, s raznim uređajima. Tehnologija višestruko djeluje na prodavače, a primarno zamjenjuje njihov rad, pa je prodavača u trgovini sve manje. Nadalje, uređaji lišavaju rad prodavača tradicionalnih kvaliteta, kao što je kreativnost i osobno odlučivanje, te njihove poslove svode na jednostavne, fizičke i rutinske radnje: ...radim automatski, imam dnevno $i$ do dvjesto računa, ja više ne znam što sam napravila. Tako prodavači zapravo postaju dodatak tehnologiji koja obavlja složenije operacije negoli sam radnik. Međutim, kada uređaj pogriješi, u tom slučaju krivicu snosi prodavač: Zna se dogoditi da senzor ne registrira kod, pa da na računu bude viša cijena, a ja to ne mogu vidjeti... kupcu se moram ispričati i vratiti novac.

"Otvorenost" radnog mjesta i dugi radni sati omogućuju prodavačima uvid u gotovo sva zbivanja u potrošačkom prostoru, iz čega proizlazi kritička percepcija kupaca i potrošnje. Prema tvrdnjama prodavačice: Ljudi su postali ovisnici o kupovanju... Onda ta pohlepa, moram nešto imati, da se pokaže, da to netko prepozna, I to "provuče" na 36 rata... meni je to nepojmljivo... Kritički se procjenjuje i potrošački prostor gdje se u odnosu na djecu daje prednost kupovini: Ostave djecu u igraonici satima, djeca se izgube u Centru pa zovu roditelje preko zvučnika..., kao i dugi boravci kupaca u trgovini: Ne razumijem što oni rade s malom djecom ovdje do zadnjeg časa u 9 sati navečer?! Sve se to konačno manifestira u osobnom stavu odbojnosti prodavača prema potrošnji: Dosta mi je dućana! Ja koja sam nekad uživala u biranju i kupovini, više nemam volje kupovati.

Za razliku od potrošača kojima je trgovački centar mjesto ugode i dokolice, za prodavače je trgovački centar mjesto prekomjerne, upadljive potrošnje, besmisleno dugih boravaka, lažne socijalizacije i eksploatacije. Razlike u percepciji ovog prostora proizlaze iz toga što je za prodavače trgovački centar nužnost, radni prostor, gdje osiguravaju svoju egzistenciju. Kako slikovito kaže W. S. Kowinski, "oni su u mallu, u dugo rastegnutom vremenu. Svakog radnog sata u danu, svih dana i tjedna u godini, uključujući većinu praznika, oni su zatočenici malla”, utamničeni "...u ovom bezvremenom, bezmjesnom prostoru, odsječeni od vani i uhvaćeni u moćnom okruženju dizajniranom za druge svrhe nego što je očuvanje njihove razumnosti" (2002.:409).

Drugo, prodavači su u trgovačkom centru, zahvaljujući prostoru i tehnologijama, minimalno potrebni. Ovdje proizvode prodaje sam prostor, koji je posebno diza- 
jniran i opremljen kako bi preuzeo ulogu prodavača i manipulirao potrošačima. Također, proizvodi prodaju sami sebe, svojom privlačnošću, bojama, modernim linijama, markama, ili izloženi u posebno osvijetljenim i aranžiranim izlozima, na vitkim lutkama. Tako prostor, proizvodi i tehnologija preuzimaju kreativne funkcije posla prodavača, pojednostavljuju njihov rad i svode ga na rutinske, simplificirane akcije. Prema G. Ritzeru, u suvremenom društvu najviše su dehumanizirani poslovi prodavača. To su poslovi koji ne traže posebne vještine, ne ostavljaju mogućnost za kreativnost, niti za osobno donošenje odluka, nego su svedeni su na rutinske postupke i ponašanja uz naučenu i neiskrenu komunikaciju. Efikasnost i jednostavne operacije rada prodavača određuju ih McJobs poslovima, koje obilježava svih pet dimenzija Mcdonaldizacije društva (Ritzer, 2004.:60). ${ }^{16}$

\section{Zaključna razmatranja}

Suvremeni potrošački prostor je komodificirano i kontrolirano mjesto, medij koji svojim materijalnim i nematerijalnim obilježjima odašilje stimulativnu poruku. Distinktivna arhitektura i dizajn, uz ugodu u simuliranom urbanom prostoru, neuočljive manipulacije i kontrole evociraju ambijent koji potiče potrošnju. Prema podacima, poruka prostora u većini dopire do destinacije, te postiže cilj manipulacije osjetilima, kretanjima i ponašanjem, pa potrošač postaje objekt "kojega se može navoditi, zavoditi trikovima, strategijama i igrama dizajna” (Goss, 1993.:32), kako bi u konačnici bio postignut krajnji efekt ovog prostornog mehanizma, što je povećanje potrošnje i ostvarenje profita.

Manipulativni potencijali ovog prostora omogućeni su zatvorenošću, zaštićenošću i kontrolom (Kowinski, 2002.:91), kreacijom nove stvarnosti, hiperrealnog prostora obilježenog pseudo objektima i pseudo događajima (Baudrillard, 2003.:126), te simulacijama koje pridonose eroziji razlike stvarnog i imaginarnog, pravog i lažnog, zahvaljujući kojima se katedrale potrošnje ponovno začaravaju i tako nastavljaju privlačiti što veći broj kupaca (Ritzer, 2005.:113).

Privlačnost, socijalni aspekti dolaska i kupovine, dužina boravka i drugo što su pokazali podaci, uistinu određuje potrošački prostor kao socijalno mjesto i vrijeme što uključuje mnoge vrste socijalnih aktivnosti i socijalnih odnosa, kao "kompleksni socijalni događaj i instituciju" (Slater, 2006.53-54). Međutim, ta neosporna socijalna živost može se tumačiti i kao značajno limitirana. Premda su trgovački centri postali mjesta okupljanja, u njima se održavaju zabave i predstave, neki od njih "udomljavaju crkve, urede, uprave, knjižnice i škole, baš kao nekad tradicionalne javne tržnice, mall nije niti sasvim javno mjesto, niti slobodna tržnica" (Kowinski,

16 McDonaldizacija društva je proces kojim principi fast-food restorana dominiraju mnogim sektorima društva. Dimenzije koje su osigurale uspješnost McDonald modela su: efikasnost, kalkulabilnost, predvidljivost, zamjena humane nehumanom tehnologijom i iracionalnost racionalnosti (Ritzer, 1999.). 
2002.:432). Ključno je da se sav taj socijalni život odvija u potrošačkom prostoru simuliranih odnosa i izvještačene komunikacije, u kojem su akteri manipulirani i kontrolirani ili pridodati tehnologijama, prostoru sa specifičnim svrhama i ciljevima, koji je "dizajniran da proizvede osjećaje, psihološke efekte i mentalna stanja" (2002.:404). To je umjetni okoliš u zatvorenom prostoru, generiran da potiče potrošačke aktivnosti, a ne osobne odnose i socijalnu bliskost. Interakcije i komunikacije u potrošačkom prostoru motivirane su manipulativnim i kontrolabilnim mehanizmima povećanja potrošnje, a socijalnost je površinska, kojoj je primarni povod ne osobni, nego kontakt s potrošačkim objektima. Međutim, kvantitativna živost i vrhunski dizajn prikrivaju da se ovdje radi o prividu socijalnosti, jer "nismo uvijek svjesni prostora i njegove sposobnosti da promiče značenja stvari i arhitekture koja svjesno konstruira i kontrolira neke aspekte prostora" (Gaines, 2006.:179). Kod potrošačkih prostora, takve su namjere dobro prikrivene; "alijenacija u potrošnji skrivena je pod maskom karnevala, patinom nostalgije i ironične esencije nekog drugog mjesta" (Goss, 1993.:40).

Stoga smo skloni zaključiti kako moderni potrošački prostori daju iskrivljenu sliku socijalnih odnosa. Trgovački centri slove kao obiteljska mjesta, gdje članovi obitelji zajedno provode slobodno vrijeme kao rijetko gdje u suvremenom društvu, što bi moglo ukazivati na reintegraciju ove grupe. Međutim, radi se o prividnom jedinstvu koje je uvjetovano potrošačkim imperativima. Svakodnevni život, u ovom slučaju obiteljski, posredovan je potrošačkim društvom, kako kaže G. Ritzer, u kasnokapitalističkom društvu oblicima socijalne kohezije, kao obitelj ili zajednica, trebaju potrošna dobra da bi učvrstili svoje odnose (Ritzer, 2001.:184). Prema ovom autoru nova sredstva potrošnje transformiraju prirodu socijalnih odnosa. U ranijim potrošačkim mjestima ti su odnosi bili dublji, face-to-face odnosi između potrošača i onih koji ih poslužuju. Oni su se željeli bolje upoznati, a socijalni karakter potrošnje bio je važan, ako ne i važniji, od onoga što se kupovalo. U današnjim prostorima potrošnje takvi su odnosi reducirani ili sasvim eliminirani. Malo je ljudi danas koji idu u nova sredstva potrošnje zbog socijalnih odnosa, prije oni idu tamo da bi brzo i što je moguće neosobnije kupili ono što žele (2005.:37-38). Interakcija je u potrošačkim prostorima, prema G. Ritzeru, sve više orijentirana ka nehumanim strukturama i mjestima, prema stvarima, te sve učestalija s ljudima koji su prisiljeni ponašati se na neljudski način (2005:185-186), pa su stoga nova sredstva potrošnje dio postsocijlanog svijeta (2005.:37). U tom svijetu postsocijalni odnosi zamjenjuju tradicionalne ljudske veze, pri čemu interakcija, prostor, pa čak i komunikacija počinju značiti nešto drugo od onoga što ti pojmovi podrazumijevaju. Ključnu činjenicu u ovom procesu, a to je značenje drugoga, naglašavaju K. Knorr Cetina i U. Bruegger, kada kažu da po prvi put u novijoj povijesti postaje nejasno jesu li za pojedince drugi ljudi zaista najfascinantniji dio njihova okoliša dio kojemu će posvetiti najveću pažnju (2002.:163).

Postsocijalna potrošnja koju obilježava individualizacija i orijentiranost sebi, u kojoj robe zauzimaju mjesta i funkcije drugih, odražava stanje u postsocijalnom svijetu, čija je priroda asocijalnost i otuđenje. Međutim, za razliku od vremena Marxa, danas se otuđenje odvija u potpunoj ugodi. Taj suvremeni spoj otuđenja i ugode, 
u kontekstu potrošnje, lijepo ilustrira prikaz W. S. Kowinskog: "žuborenje fontana, žamor ljudi, uglavnom bez ometajućih zvukova koji će razbiti vaše lebdjenje... samo nježni cirkus, vizualna parada odjeće, tvorničkih etiketa i uputa za pranje... druge figure klize pored vas, šetajući modeli proizvoda malla ili šetajući modeli bizarnosti... to je cijela ideja ove psihološke strukture. Da isključi razum i dozvoli lebdjenje, da stvori direktnu, ali ograničenu vezu između gledanja i kupovanja i što više kupujete, to vam postaje sve lakše" (2002.:404-405).

Nedostatak spontane socijabilnosti, kao povezivanja, uzajamnosti i refleksivnosti među ljudima u potrošačkim prostorima, mogao bi se, u kontekstu suvremenih promjena, tumačiti kao benigna i sporedna pojava, koja pripada sferi manje važnih svakodnevnih praksi. Međutim, dimenzije promijenjene socijalnosti znatno su šire, jer postsocijalni ljudi i postsocijalni procesi egzistiraju i u ostalim prostorima i aktivnostima suvremenog života. Na bit i težinu ovog problema ukazao je G. Ritzer, a radi se o, prema njegovim riječima, najuznemirujućoj implikaciji teze o McDonaldizaciji, kao dijalektici između onih koji žive u McDonaldiziranom društvu i onih koji rade McDonaldizirane poslove, čime se umanjuje svaka mogućnost pobune, pa tako McDonaldizacija postaje željezni kavez kojega je opisao M. Weber iz kojega nama bijega i što je još gore, niti interesa da se iz njega pobjegne (Ritzer, 2004.:67).

\section{Literatura}

1. Augé, M. (2001). Nemjesta. Uvod u moguću antropologiju supermoderniteta. Karlovac: Naklada Društva arhitekata, građevinara i geodeta.

2. Baudrillard, J. (2003). The Consumer Society. Myths and Structures. London: Sage Publications.

3. Bauman, Z. (2009). Fluidni život. Novi Sad: Mediterran publishing.

4. Deskar Škrbić, M. (2009). Keynes u 21. stoljeću. Aren't we all Keynesian now? Manager. Pregledano 12.07.2009. (http://www.manager-magazine.com/content/view/74/1/).

5. Gaines, E. (2006). Communication and the Semiotics of Space. Journal of Creative Communications, 18(2):173-181.

6. Goss, J. (1988). The Built Environment and Social Theory: Towards an Architectural Geography. Professional Geographer, 40(4):392-403.

7. Goss, J. (1993). The "Magic of the Mall": An Analysis of Forum, Function, and Meaning in the Contemporary Retail Built Environment. Annals of the Association of American Geographers, 83(1):18-47.

8. Jakovčić, M. (2004). Razvoj i funkcije trgovačkih centara na rubu grada - primjer trgovačkog centra King Cross. Pregledano 08.11.2004. (http://www.geografija.hr/novosti.asp?id_novosti $=446 \& i d \_p r o j e k t a=0 \& i d \_s t r a n i c e=0$ ).

9. Jewell, N. (2001). The Fall and Rise of the British Mall. The Journal of Architecture, 6(4):317-378.

10. Knorr Cetina, K. i Bruegger, U. (2002). Traders Engagement with Marcets: A Postsocial Realtionship. Theory, Culture \& Society, 19(5/6):161-185.

11. Kowinski, W. S. (2002). The Malling of America. Travels in the United States of Shopping. USA: Xlibris Corporation. 
12. Lebow, V. (1955). Price Competition in 1955. Journal of Retailing, 31(1):5-11.

13. Lefebvre, H. (2008). The Production of Space. Malden, Oxford: Blackwell Publishing.

14. Lipovetsky, G. (1987). Doba praznine: ogledi o savremenom individualizmu. Novi Sad: Književna zajednica Novog Sada.

15. Lipovetsky, G. (2008). Paradoksalna sreća. Ogled o hiperpotrošačkom društvu. Zagreb: Antibarbarus.

16. Lukić, A. (2002). Socijalne funkcije trgovačko-poslovnog središta: primjer Centra Kaptol u Zagrebu. Hrvatski geografski glasnik, 64:73-94.

17. Manzo, J. (2005). Social Control and the Management of "Personal" Space in Shopping Malls. Space \& Culture, 8(1):83-97.

18. Nie, N. H. (2001). Sociability, Interpersonal Relations, and the Internet: Reconciling Conflicting Findings. American Behavioral Scientist, 45(3):420-435.

19. Ozdemir, A. (2008). Shopping Malls: Measuring Interpersonal Distance Under Changing Conditions and Across Cultures. Field Methods, 20(3):226-248.

20. Ritzer, G. (1999). McDonaldizacija društva. Istraživanje mijenjajućeg karaktera suvremenog društvenog života. Zagreb: Naklada Jesenski i Turk.

21. Ritzer, G. (2004). The McDonaldization Thesis. Explorations and Extensions. London: Sage Publications.

22. Ritzer, G. (2005). Enchanting a Disenchanted World: Revolutionizing the Means of Consumption. London: Sage Publications.

23. Ritzer, G. i Stillman, T. (2001). The Modern Las Vegas Casino-Hotel: The Paradigmatic New Means of Consumption. Management, 4(3):83-99.

24. Rushokoff, D. (2002). Iznuđivanje: zašto slušamo što nam oni kažu?. Zagreb: Bulaja naklada.

25. Schor J. B. (1998). The Overspent American: Why We Want What We Don't Need. New York: Basic Books.

26. Schor, J. B. (2003). The Commodification of Childhood: Tales from the Advertising Front Lines. Hedgehog Review, 5(2):7-23.

27. Schor J. B. (2004). Born to Buy: The Commercialized Child and the New Consumer Culture. New York: Scribner.

28. Slater, D. (1997-2006). Consumer Culture and Modernity. Cambridge: Polity Press.

29. Stanić, S. (2008). Suvremeno društvo i fenomen potrošnje: Primjer trgovačkog centra Mercator centar Split. Doktorska disertacija. Zagreb: Filozofski fakultet.

30. Underhill, P. (2000). Why We Buy. The Science of Shopping. New York: Simon\&Schuster.

31. Underhill, P (2005). The Call of the Mall: The Geography of Shopping. New York: Simon\&Schuster.

32. Zukin, S. (1998). Urban Lifestyles: Diversity and Standardization in Spaces of Consumption. Urban Studies, 35(5-6):825-839. 
Original scientific paper

\author{
Sanja Stanić \\ Filozofski fakultet Sveučilišta u Splitu \\ Odsjek za sociologiju \\ e-mail: sstanic@ffst.hr
}

\title{
(Post)sociality in Contemporary Consumption Space
}

\begin{abstract}
In the article a shopping centre is considered as a representative of the contemporary consumption space. In these structures contents and offers are carefully combined, while shopping can be done effectively and in a pleasant environment. Shopping time and leisure activities merge here into the unique time of consumption while the space becomes a scene of getting together and social vibrancy. Based on the research results, the paper discusses the sociality in a shopping center. Consumption space is seen as a place of interaction between space and actors, and actors themselves.

Obtained results indicate that a shopping center is a created environment, which, with the elements of interior design, amenities and atmospherics sends a message whose basic aim is encouraging consumption. Although a shopping center is a public place and shopping and consumption are social activities, in this consumer environment sociality is false and limited. Technologies increasingly replace the salespersons' work and they become machine adjuncts. Traditional qualities of their work are minimized and their communication is insincere and learned. The conclusion emphasizes the fact that in the modern consumption space social relations are transformed into the postsocial ones and marked by the loss of spontaneity and reciprocity. At the same time human relations are replaced by thing relations.
\end{abstract}

Key words: sociality, consumption, space, manipulation, interaction, salesmen, consumers, postsocial relations. 